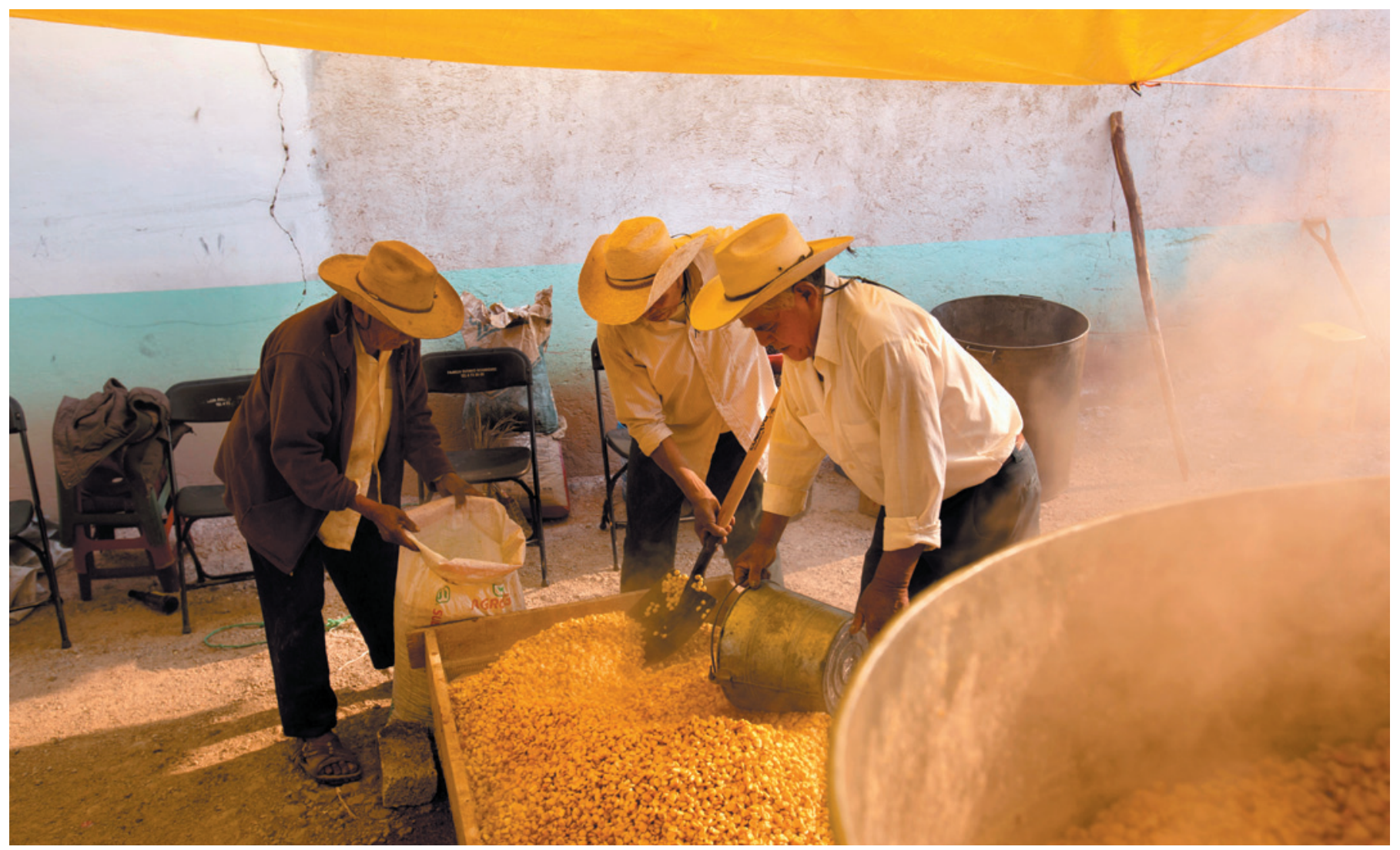

Maize is central to Mexican cuisine, culture and economy, but the formerly self-sufficient country now imports about one-third of its supply.

\title{
GM maize splits Mexico
}

\section{Legal challenge to transgenic crops has created a rift in the country's scientific community.}

\section{BY LAURA VARGAS-PARADA}

$\mathrm{T}$ he Mexican scientific community has been torn apart by a legal battle over transgenic maize (corn). Almost a year after activists challenged scientists' right to plant experimental genetically modified (GM) varieties of the crop that is a staple and symbol of Mexico, maize research is still being stymied by a legal stalemate.

On 5 July 2013, a coalition of activist groups filed a class-action lawsuit to stop the Mexican government granting permits to plant GM maize. That September, a judge ordered a halt to experimental and commercial planting until a final verdict is reached - a resolution that could take months or years.

The lawsuit and ruling have thwarted the plans of multinational companies such as Monsanto, DuPont Pioneer and Dow AgroSciences, which have lobbied for more than a decade to sell their GM maize varieties to Mexican farmers. But they have also stalled public-sector biotechnology researchers who say they are close to producing GM maize strains tolerant to drought and frost, and other varieties with a reduced need for herbicides and fertilizers. These researchers complain that the lawsuit threatens to derail work that could boost maize yields, reduce imports and help to protect against threats such as climate change.

"We are very frustrated, and there is a general sense of despair," says Beatriz Xoconostle, a plant biotechnologist at the Center for Research and Advanced Studies (Cinvestav) in Mexico City who leads a project to develop drought-tolerant GM maize. "We have been unable to accomplish our objectives."

Mexico has neither embraced GM technology nor run from it. In 2010, the agriculture and environment ministries authorized commercial planting of GM cotton, and approval for transgenic soya beans followed two years later. By 2013, the country was growing 100,000 hectares of engineered crops more than any European nation except Spain, although much less than Brazil and Argentina.

But in Mexico, the question of government approval - and public acceptance - of GM maize is much more sensitive. Fears were stoked in 2001, after researchers at the University of California, Berkeley, reported that genetic material from GM maize had flowed into local populations of native maize cultivars (D. Quist and I. H. Chapela Nature 414, 541543 ; 2001). For years afterwards, even experimental plantings of GM maize were banned.

In 2009, Monsanto, Dow and DuPont Pioneer were granted approval to grow GM maize for research - as were some academic researchers (see 'Transgenic tussle'). But those programmes were halted again by the 2013 lawsuit, which was spearheaded by agronomist Adelita San Vicente of the Seeds of Life Foundation, a non-profit organization in Mexico City that opposes GM crops. The suit claimed that transgenic maize threatens the biodiversity of traditional varieties grown by subsistence farmers and smallholders throughout Mexico.

Mexico's caution over the introduction of GM maize reflects a deep desire to conserve genetic diversity in a crop that is central to the nation's identity. In the United States, the vast majority of maize is grown to feed livestock 


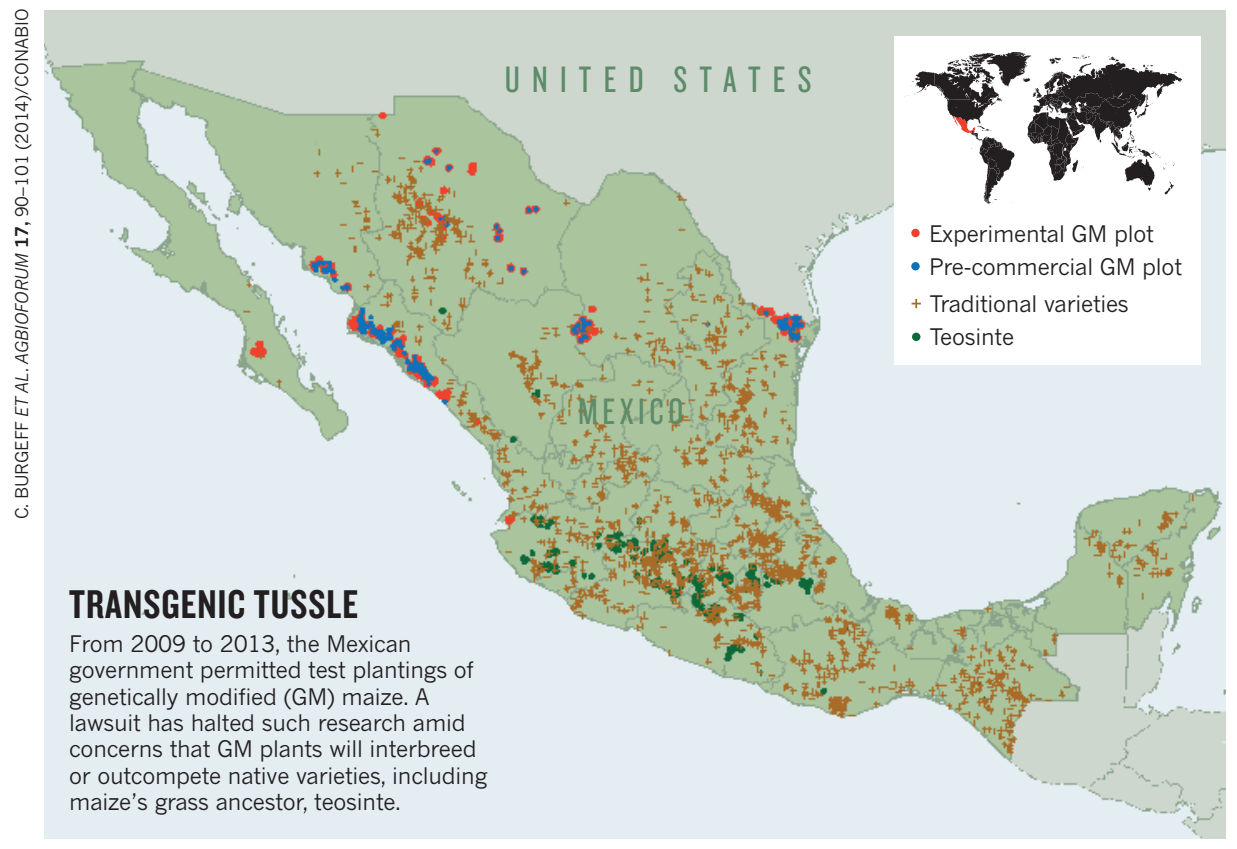

and produce ethanol fuel. But in Mexico, $82 \%$ of white maize is grown for human consumption, often on small farms planted with traditional, rather than commercial, varieties.

"The richness of genetic diversity of maize in Mexico is invaluable," says José Sarukhán, national coordinator of the National Commission for Knowledge and Use of Biodiversity (CONABIO), a government research council created in 1992. Sarukhán and other ecologists at CONABIO worry about gene flow from GM to native varieties, and that the wide adoption of GM maize could displace them. They are also concerned that GM seed producers might take legal action against small farmers whose seed ends up containing transgenic material.

"We are not against transgenic maize, but want to raise awareness of the implications of their use, and the consequences when they mix with local varieties," says CONABIO plant geneticist Francisca Acevedo.

Once self-sufficient, Mexico now imports about a third of its maize, most of it from the United States. Scientists who oppose GM maize argue that domestic production could be boosted with irrigation and infrastructure projects, expanded agricultural-extension education programmes for farmers and careful selection of hybrid seeds and native varieties.

But government scientists, including Luis Herrera-Estrella, director of the National Laboratory of Genomics for Biodiversity at Cinvestav, see biotechnology as a crucial tool for restoring the country's maize independence. Xoconostle's project, for example, seeks to develop drought-tolerant GM maize that can also resist low temperatures. Using antisense RNA, she and her team have modified the plant's metabolism by inhibiting an enzyme that destroys trehalose, a sugar involved in stress response. The result, a variety called CIEA-9, requires only two-thirds of the water needed by a normal plant. "This strategy is a way to save many of our local maize varieties," says Xoconostle.

The next stage of this research, and the last step required by Mexican law before Xoconostle can apply for a permit for commercial planting, will be to cultivate 4 -hectare experimental plots of CIEA-9 to test productivity. But the team will have to wait until a final decision has been made on the lawsuit before they can go ahead.

Other government crop scientists have kept their research going by moving their field trials to other countries. In "We are very November, Herrerafrustrated Estrella obtained a and there is a permit to plant experigeneral sense mental plots in Argenfina. He leads a group developing transgenic maize and soya that require reduced amounts of fertilizer and compete well against weeds. The transgenic plants work by expressing a bacterial gene that codes for phosphite oxidoreductase, an enzyme that transforms the soil mineral phosphite into phosphate, which most plants need to grow and produce energy (D. L. López-Arredondo and L. Herrera-Estrella Nature Biotechnol. 30, 889-893; 2012).

In Argentina, Herrera-Estrella says, regulatory requirements are "more accessible, science-based and sensible". In Mexico, more than 100 requirements must be fulfilled before a researcher can obtain a permit for experimental planting; some, he says, make the process unaffordable.

But despite her frustration with the current planting moratorium, Xoconostle does not see Mexico's stringent policies as a problem. "I am happy we have a strict law that regulates very precisely what we will allow to be grown in Mexico," she says. 